\title{
Quieting the Rebellion: Eliminating Payment of Prepetition Debts Prior to Chapter 11 Reorganizations
}

\author{
Joshua A. Ehrenfeld $\dagger$
}

Imagine "Milton's," a hypothetical office supply store with serious financial problems. Milton's cannot sell enough office supplies to meet its various financial obligations: It owes money to numerous creditors, including its suppliers of staplers, notebooks, and pencils.' Because Milton's does not have enough money to pay its creditors, it has two realistic options: a) it can attempt to pay off certain creditors, and leave others unpaid; ${ }^{2}$ or $b$ ) it can seek the protection of the Federal Bankruptcy Code. ${ }^{3}$

Ideally, the Bankruptcy Code will protect both debtors and creditors and will facilitate an orderly and fair reorganization process. In reality, however, the system works differently. Imagine that the Christmas shopping season is quickly approaching and Milton's must have staplers from Supplier A and pencils from Supplier B if it wishes to have a successful Christmas season and continue operating. ${ }^{4}$ Unfortunately, Suppliers A and B have not been paid for earlier shipments of staplers and pencils. Although the Bankruptcy Code prohibits them from acting to collect on previous debts, nothing requires them to continue shipping supplies to a 'store that owes them money. ${ }^{5}$ In order to solve this problem, parties "circumvent" the Bankruptcy Code by persuading a court to grant payments to these "necessary" or "essential" prepetition creditors. ${ }^{6}$

$\dagger$ B.A. 1999, The College of William and Mary; J.D. Candidate 2003, The University of Chicago.

Although it owes different amounts to various creditors, Milton's cannot afford to pay any creditor back in full. Thus, Milton's numerous creditors will likely attempt to seize its limited assets through lawsuits, in an effort to recover debts owed to them.

2 This option would create the undesirable outcome in which Milton's would have to cease operating, because it would use its scarce assets to pay back creditors instead of spending the money to maintain and operate the business.

3 This hypothetical assumes that one of Milton's goals is to stay in business. Milton's and similar firms frequently seek bankruptcy protection to keep their operations intact because the overall goal of Chapter 11 of the Bankruptcy Code is to provide a forum to assist in successfully reorganizing distressed firms. See Part I.

4 This hypothetical is loosely based on the facts in In re Just for Feet, Inc, 242 BR 821, 82224 (D Del 1999) (regarding a company's claim that it needed to stock its shelves with the major manufacturers' latest shoes to have a successful Christmas season). See Part II.B.

5 See Part I.

6 These payments are known as "prepetition payments," which comprise any payment made after a bankruptcy petition is filed, in consideration of a debt that existed before the filing. 
Although some federal district and bankruptcy courts grant prepetition payments, the federal circuit courts of appeal have determined that such payments violate the spirit and letter of the Bankruptcy Code. Nonetheless, parties continue to move for prepetition payments, lower courts continue to grant these motions, and this quiet bankruptcy "rebellion" continues without much fanfare, debate, or analysis. ${ }^{8}$

The split between lower and higher courts raises several important issues. The first is whether the provisions of the Bankruptcy Code permit courts to allow payment of prepetition debts prior to reorganization. In addition, it is important to determine the impact of resolving the differences between lower and higher federal courts on the very debtors the Code was designed to protect and on the efficiency of the bankruptcy system as a whole.

This Comment will seek to answer both questions. Part I discusses the overall scheme of the Bankruptcy Code, explains the relevant statutory language, describes prepetition payments, and sets forth the justifications used to permit these payments. Part II describes the unique dispute and split of authority over prepetition payments and analyzes the reasoning that underlies the opinions of both sides. Finally, Part III proposes a solution to conform bankruptcy practice to the Code's parameters in order to resolve the dispute detailed in Part II. This Comment ultimately proposes that the federal appellate courts are correct in their interpretation of the Bankruptcy Code, and argues that enforcing the appellate courts' decisions by eliminating prepetition payments is necessary to maintain order within the current bankruptcy regime.

\section{THE FEDERAL BANKRUPTCY REgIME}

In order to address and resolve the judicial split, one must understand both the basic structure of the federal bankruptcy regime and the justifications offered for prepetition payments.

\section{A. Essential Elements of the Bankruptcy Code}

The United States Bankruptcy Code creates a forum in which distressed firms can file petitions for bankruptcy protection in order to

This Comment uses the phrase "circumvention" to describe the process of avoiding the automatic stay's requirements through prepetition payments. See Part I.B.

7 This Comment uses the phrase "lower federal courts" to describe both the United States Federal District Courts and Federal Bankruptcy Courts. See Part II.

8 See, for example, Just for Feet, 242 BR at 826 (allowing prepetition payments and citing other decisions where courts granted such payments without discussion). See also note 67; Part II.B. 
stave off creditors and reorganize in an attempt to continue operations.' Although the Code sets forth a complex statutory scheme, firms reorganizing under Chapter 11 will generally use three specific tools: the automatic stay, the priority scheme, and the requirement of judicial confirmation.

1. The automatic stay and the priority scheme.

The Bankruptcy Code's primary mechanism, the automatic stay provision, prohibits any creditor from attempting to foreclose on the debtor's assets until the debtor has had sufficient time to reorganize." Contained in Section 362," the automatic stay prohibits a firm's creditors from taking any affirmative steps to recover debts owed prior to the filing of the firm's bankruptcy petition. ${ }^{12}$ In doing so, the automatic stay prevents a creditors' race to the debtor's assets, ${ }^{13}$ while affording the debtor time to engage in a judicially-supervised reorganization process. ${ }^{14}$

In addition, the Code operates by creating an organizational scheme in which creditors' claims are given a certain priority. ${ }^{15}$ This priority scheme, commonly referred to as the "absolute priority rule,"

9 See Thomas H. Jackson, Of Liquidation, Continuation, and Delay: An Analysis of Bankruptcy Policy and Nonbankruptcy Rules, 60 Am Bankr L J 399, 399 (1986) (stating that the recognized goal of bankruptcy law is ensuring that creditors do not make a bad situation worse by engaging in a destructive race to the debtor's assets).

10 The automatic stay thus prevents the hypothetical Milton's various suppliers from collecting, or attempting to collect, payment for debts before the store has had the opportunity to reorganize. See 11 USC $\$ 362$ (2000) (providing for a stay on any attempt to seize or claim assets of a party that has filed for bankruptcy protection).

11 Section 362 prevents "any act to create, perfect, or enforce against property of the debtor, any lien to the extent that such lien secures a claim that arose before the commencement of the case under this title." 11 USC \$ 362(a)(5). See Douglas G. Baird, Thomas H. Jackson, and Barry E. Adler, Bankruptcy: Cases, Problems, and Materials 89-90 (Foundation 3d rev ed 2001) (stating that the Bankruptcy Code freezes the debtor's affairs at the time the bankruptcy petition is filed and that a creditor with a prepetition claim must await payment from the collective bankruptcy process).

12 See Douglas G. Baird, Elements of Bankruptcy 11 (Foundation 3d ed 2001) (stating that Section 362 requires all creditors to cease all debt collection efforts the moment a bankruptcy petition is filed).

13 Preventing a creditors' race is one of the Code's most important functions. A distressed firm frequently has insufficient assets available to fulfill its various financial obligations. Attempting to remove these finite assets destroys the firm's value and ability to operate. See Jackson, $60 \mathrm{Am}$ Bankr L J at 402 (cited in note 9) (stating that when creditors attempt to grab assets from the debtor instead of cooperating to leave the assets in place, the debtor's going-concern value can be destroyed).

14 See Baird, Jackson, and Adler, Bankruptcy at 88 (cited in note 11) (stating that the automatic stay is designed to prevent a "race to a debtor's assets").

15 See 11 USC $\$ 1129$ (b)(1) ("[T]he court ... shall confirm the plan ... if the plan does not discriminate unfairly, and is fair and equitable, with respect to each class of claims or interests that is impaired under ... the plan."). 
treats creditors equally vis-à-vis the debtor, by placing a firm's various creditors on equal footing during the reorganization process.

\section{Reorganization plans and judicial confirmation.}

The Code provides specific guidelines under which a debtor may propose and pass a reorganization plan. ${ }^{17}$ Once a plan is passed, judicial approval ${ }^{18}$ is required before it goes into effect. ${ }^{19}$ Under the bankruptcy system, claims that arise prior to the filing of a bankruptcy petition cannot be paid until a reorganization scheme is confirmed and implemented. ${ }^{20}$

The crucial aspect of this statutory scheme lies in Section 1121 and Bankruptcy Rule 3021. ${ }^{21}$ Section 1121 of the Code provides the means by which a debtor can file a plan of reorganization, ${ }^{22}$ and sets forth, in conjunction with Sections 1122-29, the requirements for passing the plan. ${ }^{23}$ Rule 3021, which helps set forth the order of priority for distribution of payments under a plan, protects creditors who have used the proper process by placing their claims in an equitable order. ${ }^{24}$ This statutory scheme is subverted when certain creditors receive

16 The absolute priority rule requires that all similarly situated creditors be treated equally. In the context of the hypothetical Milton's, all of its suppliers are unsecured creditors necessitating equal treatment under the absolute priority rule. Thus, paying certain suppliers before others would violate the Code's priority scheme. See Baird, Elements of Bankruptcy at 74 (cited in note 12) (explaining that application of bankruptcy's absolute priority rule entails treating similarly situated creditors equally such that if two classes of creditors have claims or interests of identical priority, absent some special circumstance that would justify subordination of one class, a plan cannot provide less to one class than to another).

17 A successful reorganization plan is the ultimate goal of Chapter 11. When implemented, a plan alters the financial structure of a firm to reduce its debt and allow for continued operations. See Baird, Elements of Bankruptcy at 17-18 (cited in note 12). See also 11 USC $\$ \$ 1121-29$ (setting forth provisions governing the filing of plans; the classification of claims and interests; the required contents of plans; the impairment of claims; and the acceptance, modification, and confirmation of plans).

18 The Bankruptcy Code refers to this approval as judicial "confirmation." See 11 USC $\S \S 1128-29$ (requiring that the court hold a confirmation hearing and outlining the requirements for judicial confirmation).

19 Creditors may seek payment of debts only after a plan is confirmed, see 11 USC $\$ 362$ (providing for an automatic stay on collection actions once a bankruptcy case has been commenced), and payment to creditors occurs subject to the specific terms implemented in the reorganization plan approved by the Bankruptcy Court. See 11 USC $\$ \S 1141-42$ (providing for creditors to be able to recover debts in accordance with the reorganization plan).

20 See 11 USC $\$ 362$ (staying collection actions once bankruptcy is declared); 11 USC $\S \S 1141-42$ (providing for creditors to recover in accordance with a reorganization plan or appropriate order).

21 See 11 USC $\$ 1121$; FRBP 3021 (2000).

22 See 11 USC $\$ 1121$ (stating that only a debtor may file a plan of reorganization within the initial 120 days of filing a bankruptcy petition).

23 See note 17.

24 See FRBP 3021 (allowing claim distribution for creditors who have followed procedure). 
payment before other similarly situated creditors. ${ }^{25}$ The prevention of prepetition payments thus serves to place all of a firm's creditors on equal footing during the reorganization process. ${ }^{26}$

\section{B. Bankruptcy Code Circumvention: Payment of Debts Prior to Reorganization}

Despite the Bankruptcy Code's statutory treatment of claims, in reality all creditors are not created equal. ${ }^{27}$ The automatic stay and priority schemes can be problematic, as they prevent the firm from treating its important suppliers favorably. Thus, parties use prepetition payments to circumvent the Code's provisions in an attempt to maintain the firm's most important working relationships. ${ }^{28}$

1. Necessary and essential creditors and suppliers.

Certain supplies can be more essential to a firm than others. ${ }^{29}$ In the context of the hypothetical Milton's, for example, Swingline Staplers are likely more important to its business than a lesser known brand of staplers because name-brand staplers tend to attract more business. ${ }^{30}$ Yet, the Bankruptcy Code makes no distinctions between claims arising from more important suppliers and those arising from less important ones: Its provisions apply equally to all creditors. ${ }^{3.1}$ Thus, the Bankruptcy Code does not necessarily account for the economic realities facing a failing firm.

Distressed firms may find that receiving continued supplies from some creditors is necessary to continue operating. ${ }^{32}$ This need inevitably gives these creditors a certain amount of leverage over the

25 See 11 USC $\$ 1122$ ("[A] plan may place a claim or an interest in a particular class only if such claim or interest is substantially similar to the other claims or interests of such class").

26 See note 16.

27 Although a firm's suppliers would all receive equal treatment under the Code, sometimes certain suppliers are more important to a firm than others. See Baird, Elements of Bankruptcy at 190 (cited in note 12) (stating that in many cases the debtor may want to continue doing business with certain suppliers, making them both prepetition creditors and postpetition suppliers).

28 Prepetition payments are thus a means to ensure that important parties are willing to maintain business relationships with the distressed firm.

29 See In re Just for Feet, Inc, 242 BR 821, 826 (D Del 1999) ("Clearly, Just for Feet cannot survive unless it has name brand sneakers and athletic apparel to sell in its stores, ... [and it needs] a continuous supply of inventory from athletic footwear and apparel vendors such as Nike.").

30 Swingline is the brand of choice among most office supply aficionados. See Geoffrey A. Fowler, Hollywood Ending: Stapler Becomes a Star, Wall St J B1 (July 2, 2002) (describing the rise of Swingline Staplers as a hot office product item in the wake of the movie "Office Space").

31 See Baird, Elements of Bankruptcy at 74 (cited in note 12) (describing bankruptcy's priority rule).

32 Some debtors cannot afford to lose certain suppliers but may survive without others. See notes 27 and 33 . 
debtor. ${ }^{33}$ The position of these important suppliers, sometimes deemed essential or necessary, holds a crucial place in the current bankruptcy regime because debtors often feel that their fate is tied to the willingness of these creditors to continue to do business. ${ }^{34}$

\section{Rationalizing payments to prepetition creditors.}

The prepetition "rebellion" did not occur out of thin air. Courts and parties use these payments because they believe them useful in facilitating the reorganization of debtors, and in creating a more efficient bankruptcy system. ${ }^{35}$ Parties attempt to justify prepetition payments through various legal theories and principles derived from both the Code itself and past bankruptcy practices.

a) Code-based justifications. One justification for prepetition payments is Section 105(a) of the Bankruptcy Code. ${ }^{36}$ Section 105(a) permits a court to issue "any order, process, or judgment that is necessary or appropriate to carry out the provisions" of the Code. 37 Some courts have interpreted Section 105(a) to grant equitable powers that allow them to circumvent the technical language of the Code prohibiting prepetition payments when doing so leads to a more just or equitable result. ${ }^{38}$ Because lower courts tend to view the bankruptcy process as a means to protect the firm's ability to operate, they frequently permit prepetition payments when they feel it necessary for the continued survival and successful reorganization of the firm.

Another statutory justification for prepetition payments stems from Section 363 of the Code, which states that the trustee of an estate

33 See Baird, Elements of Bankruptcy at 190 (cited in note 12) (noting that large suppliers wear two hats: as both prepetition creditors and postpetition suppliers, but that the extent to which they can exploit this position is unclear).

34 The terms "necessary" and "essential" creditors stem from the doctrine of necessity of the late nineteenth century, and its continued application today. See Miltenberger $v$ Logansport Railway Co, 106 US 286,311 (1882) (articulating the doctrine of necessity by stating that "[m]any circumstances may exist which may make it necessary and indispensable to the business of the road and the preservation of the property, for the receiver to pay pre-existing debts of certain classes .... Yet the discretion to do so should be exercised with very great care.").

35 See Just for Feet, 242 BR at 826 (discussing the necessity of prepetition payments to allow the debtor firm to survive during the reorganization process, and listing cases where prepetition payments were granted to vital suppliers).

3611 USC $\$ 105(a)(2000)$.

37 Id.

38 See Just for Feet, 242 BR at 824-25 (holding that Section 105(a) permitted the court, through its equitable powers, to authorize prepetition payments to vendors deemed necessary to the survival of a Chapter 11 debtor).

39 See id. See generally Brian Leepson, Note, A Case for the Use of a Broad Court Equity Power to Facilitate Chapter 11 Reorganizations, 12 Bankr Dev J 775, 798-801 (1996) (discussing the purposes of bankruptcy, and explaining that the intent of the lower courts to assist debtors in successful reorganizations frequently includes the use of prepetition payments as an effective tool to facilitate a reorganization). 
may "enter into transactions, including the sale or lease of property of the estate, in the ordinary course of business, without notice or a hearing, and may use property of the estate in the ordinary course of business." ${ }^{, 40}$ This section permits the trustee to use assets of the debtor's estate in a manner that will increase the value of the estate. One interpretation of this section would allow prepetition payments because they would increase the estate's assets by permitting the trustee to keep the debtor functioning as a going concern."

b) The doctrine of necessity. The "doctrine of necessity" is another frequently used justification for prepetition payments. This is premised on a theory that certain vendors are critical and thus necessitate special treatment in bankruptcy. The doctrine-sometimes referred to as the necessity of payment rule-stems from the late nineteenth-century bankruptcy practice that permitted receivers to pay pre-existing debts in the case of bankrupt railroads. ${ }^{42}$ The necessity of payment rule, however, exists within the current framework of the Bankruptcy Code only to assist in the narrow category of cases involving railroad reorganizations. ${ }^{43}$ Moreover, although its existence and history were no doubt known to Congress, this rule was not expanded beyond its application to railroads when the Code was last substantially amended."

\section{JUdICIAL DISOBEDIENCE: BANKRUPTCY's PECULIAR SPLIT}

When given an opportunity to speak to the issue, the appellate courts have condemned prepetition payments. Nonetheless, lower courts frequently grant these payments, creating a rare split of authority within the judicial hierarchy.

$40 \quad 11$ USC $\$ 363(c)$.

41 This theory assumes that maintaining the firm's operations will lead to an increase in its assets through the successful continuation of its business. See Baird, Elements of Bankruptcy at 192 (cited in note 12) (noting that Section 363 permits trustees to spend money in order to increase the value of the estate's assets, and that when a payment to a prepetition creditor will "increase the return to general creditors, it is arguably a use of assets within the ambit of $\S 363$ ").

42 See note 34. See also Russell A. Eisenberg and Frances F. Gecker, The Doctrine of Necessity and Its Parameters, 73 Marq L Rev 1, 2-3 (1989). Prior to the current Bankruptcy Code, this practice allowed the then-defunct railroads to continue operating by making payments to essential creditors.

43 The text of the Code only provides for the doctrine in the context of railroad reorganizations. See Baird, Elements of Bankruptcy at 194 (cited in note 12) (stating that the doctrine of necessity can be found in Section 1171(b) of the Bankruptcy Code, a section limited to railroad cases). See also note 58 .

44 See In the Matter of B\&W Enterprises, Inc, 713 F2d 534, 537 (9th Cir 1983) (refusing to alter the statutory scheme in the 1978 Bankruptcy Act to include the necessity of payment rule). The most important and substantial revisions to the Bankruptcy Code took place in the 1978 amendments. See 11 USC $§ 507$ (1979). 


\section{A. The No Circumvention Rule: The Federal Appellate Courts}

The federal appellate courts oppose prepetition payments. ${ }^{45}$ Due to the speed with which bankruptcy cases proceed, however, the opportunities for appellate courts to speak on this issue appear rare, and receive too little attention. ${ }^{46}$ Yet, despite the infrequency of these cases, the decisions and interpretations that do exist are uniform and clear: The appellate courts are opposed to prepetition payments. ${ }^{47}$ The most emphatic statement of this opposition appeared in the Fourth Circuit's decision in The Official Committee of Equity Security Holders $v \mathrm{Ma}$ bey. ${ }^{48}$ Mabey involved a judicially-approved payment, through which certain tort victims would receive compensation prior to the judicial confirmation of the debtor A.H. Robins's reorganization plan. ${ }^{49}$ The Fourth Circuit struck down the payment, stating that: "The Bankruptcy Code does not permit a distribution to unsecured creditors in a Chapter 11 proceeding except under and pursuant to a plan of reorganization that has been properly presented and approved." ${ }^{50}$ In addi-

45 See, for example, The Official Committee of Equity Security Holders v Mabey, 832 F2d $299,300,302$ (4th Cir 1987) (reversing a lower court decision that would have disbursed funds to certain prepetition creditors prior to a confirmed reorganization plan). The appellate courts' opposition to prepetition payments does not apply to railroad reorganization cases which are specifically governed by different rules under the Bankruptcy Code. See note 58 (describing the special circumstances afforded railroad reorganizations).

46 Most payments are granted in motions listed in a given case's first day orders, thus occurring too early in the process for a viable appeal to take place, and thereby preventing such orders from being reported or listed in any published record other than a given case's docket. See, for example, In re Just for Feet, Inc, 242 BR 821, 825 (D Del 1999) (listing Bankruptcy court cases granting motions to pay prepetition creditors). See also note 67 . Once a firm has filed for bankruptcy, a certain time frame limits the process, leaving little time for objection, written opinions, or formal judicial appeal. Creditors frequently have an interest in a timely reorganization because if the debtor fails to reorganize quickly, creditors may lose their part of an already small amount of assets. See, for example, Richard Tomkins, Eastern Air Poised to Emerge from Bankruptcy, Fin Times 28 (Dec 23, 1994) (reporting that the Eastern Air Lines bankruptcy plan, approved five years after the airline went into bankruptcy, would provide creditors between nine and seventeen cents on the dollar).

47 Only six circuits have spoken on the issue, and no federal appellate court appears to have expressly permitted prepetition payments except in the specific instance of a railroad reorganization. See In the Matter of Oxford Management, Inc, 4 F3d 1329, 1333-34 (5th Cir 1993) (stating that the Code did not permit payments of prepetition claims under $\$ 105(\mathrm{a})$ ); Mabey, 832 F2d at 302 (overruling a lower court's establishment of a fund to pay certain expenses before a plan was confirmed); In the Matter of B\&W Enterprises, Inc, 713 F2d 534, 538 (9th Cir 1983) (same); In the Matter of the Lehigh and New England Railway Co, 657 F2d 570, 581-82 (3d Cir 1981) (stating that there is no payment of prepetition claims under the necessity of payment rule unless the railroad's reorganization is helped by it); In re Boston and Maine Corp, 634 F2d 1359, 1382 (1st Cir 1980) (allowing payment of prepetition claims for railroad cases). See also note 58.

$48832 \mathrm{~F} 2 \mathrm{~d} 299,302$ (4th Cir 1987) (stating that such a payment has "no authority to support it in the Bankruptcy Code and violates the clear policy of Chapter 11 reorganizations").

49 This result would have in essence paid certain creditors - the tort victims-before any other of Robins's creditors, in violation of the priority scheme and the automatic stay provision. See id at $300-02$.

so Id at 302. 
tion, the court noted that the Code's "clear language" did not "authorize the payment in part or full, or the advance of monies to or for the benefit of unsecured claimants prior to the approval of the plan of reorganization." ${ }^{\text {s1 }}$

Although Mabey involved an attempted circumvention using the court's equitable powers ostensibly granted by Section $105(\mathrm{a}),{ }^{52}$ its strict textualist reading of the Code is applicable to other rationalizations for prepetition payments. ${ }^{53}$ Thus, Mabey would likely preclude reliance on the doctrine of necessity or use of the assets of the estate as a means to allow payment to necessary creditors. ${ }^{s 4}$

In another example of textualist reasoning, the Ninth Circuit, in In the Matter of $B \& W$ Enterprises, Inc, explicitly determined that the necessity of payment rule was applicable only to cases involving railroads, and refused to apply it to modern bankruptcy situations absent Congressional action altering the Code to include the rule. ${ }^{56}$ Because it could find no textual support for the grant of prepetition payments, the Ninth Circuit reasoned that it could not grant such payments without "tamper[ing] with the statutory priority scheme devised by Congress." "

There are only two instances in which appellate courts have permitted prepetition payments. Both involved railroad reorganizations, which benefit from specific rules and provisions within the Bankruptcy Code. ${ }^{38}$ Thus, except for the potential use in railroad bankruptcies, circumvention of the Code's statutory scheme appears disfavored in the federal appellate courts. Under this precedent, firms like Milton's would not be permitted to pay any of their suppliers prior to judicial confirmation of a reorganization plan.

51 Id.

52 The Fourth Circuit made clear, however, that it does not interpret Section 105(a) to allow a court equitable powers to grant prepetition payments. See id at 302 .

53 See id (refusing to allow payment to unsecured claimants prior to the approval of the plan absent a clear provision for doing so in the Rules or the Code).

54 See id.

55713 F2d 534 (9th Cir 1983).

56 The court pointed out that the necessity of payment rule existed prior to the 1978 amendments to the Bankruptcy Code, yet was not included in those amendments. See id at 537.

57 Id. See also Oxford Management, 4 F3d at 1334 (stating that the Bankruptcy Act did not give bankruptcy courts the power to allow payment of prepetition claims).

58 Railroad reorganizations are a different type of case because of the historic use of prepetition payments to facilitate their reorganizations. Further, because the Bankruptcy Code includes specific provisions and guidelines for railroad reorganizations, these cases are inherently different. Although the Code permits prepetition payments in railroad reorganizations, there is no basis for extending this grant of power to non-railroad reorganizations. See 11 USC $\$ 1161-$ 73 (2000) (setting forth provisions in the Bankruptcy Code specifically meant for use in railroad reorganizations). See also Lehigh and New England Railway, $657 \mathrm{~F} 2 \mathrm{~d}$ at 581; Boston and Maine, 634 F2d at 1382 . 


\section{B. A Clear Disregard: The Lower Federal Courts}

Regardless of the authoritative precedent, lower federal courts have granted, and continue to grant, motions for prepetition payments. ${ }^{99}$ This disregard, which stems from lower courts' recognition of practical realities facing debtors attempting to reorganize, has quietly allowed expediency and efficiency to trump authority and precedent in the current bankruptcy regime.

Published lower court opinions granting necessary payments are rare. ${ }^{61}$ Because these decisions are in essence hidden from almost everyone but bankruptcy practitioners, the judicial hierarchy does not appear threatened or even disturbed. ${ }^{62}$ Nonetheless, these cases both exist and contravene stated bankruptcy precedent.

In 1999, the United States District Court for the District of Delaware decided In re Just for Feet, $I n c{ }^{63}$ in which it determined that certain trade vendors were critical to the firm's survival and authorized prepetition payments to those vendors, despite the firm's lack of a judicially confirmed plan. ${ }^{64}$ The court relied on an interpretation of Section 105(a)'s equitable powers as providing a "statutory basis for the payment of prepetition claims," and the necessary authority to grant prepetition payments. ${ }^{65}$

The district court showed that it recognized that the realities of the case, as much as the strict language of the statute, should influence its decision-particularly since it was charged with the duty to apply equitable decisionmaking. ${ }^{66}$ The court's choice of equity over existing text partially explains the difference in outcomes between Just for Feet and appellate court precedent.

The Just for Feet court also cited various other cases in which payment of prepetition claims to vital suppliers and trade vendors had been authorized. ${ }^{67}$ Although the case only enunciated in writing what

59 See, for example, Just for Feet, $242 \mathrm{BR}$ at 826.

60 See id.

61 See note 46.

62 Records of first day orders granting prepetition payments are available through the Bankruptcy court dockets, but are generally hidden among numerous other orders.

63242 BR 821 (D Del 1999).

64 See id at 826 .

65 Id. Significantly, in making its decision, the court relied on practical implications, rather than the plain language of the Code: "Clearly, Just for Feet cannot survive unless it has name brand sneakers and athletic apparel to sell in its stores." Id.

66 Just for Feet is not the lone lower court decision recognizing the viability of prepetition payments in the current bankruptcy regime. For example, in In the Matter of the Columbia Gas System, Inc, 171 BR 189 (Bankr D Del 1994), the court, despite ultimately denying the specific prepetition payment involved, explained that prepetition payments were permitted only if necessary for the continued operation of the business. See id at 192.

67 See In re Goss Graphic Systems, Inc, Case No 99-02756 (Bankr D Del, filed July 30, 1999); In re Discovery Zone, Inc, Case No 99-00941 (D Del, filed Apr 20, 1999); In re Acme Met- 
are common ongoing practices, the decision was important because it essentially admitted in a federal reporter what had formerly been discussed only in academic circles and among bankruptcy practitioners: the existence of a vertical authoritative split between the federal appellate and lower courts. ${ }^{68}$

\section{ENDING THE CIRCUMVENTION: CONFORMING BANKRUPTCY PRACTICE TO LEGAL INTERPRETATION}

The divergence between lower court bankruptcy practice and appellate court interpretation of the Code requires a solution to address the "rebellion," and a determination of the correct legal status of prepetition payments. Because the appellate courts' approach to the problem is legally correct and authoritatively sound, the proper solution is to eliminate the practice of granting prepetition payments from the current bankruptcy regime, despite the potential adverse effects on firms attempting to use Chapter $11 .^{69}$

\section{A. Prepetition Payments and the Appellate Courts' Correct Analysis}

The current version of the Bankruptcy Code was enacted in 1978, and contains no express language allowing prepetition payments except in the specific instance of a railroad reorganization..$^{70}$ In addition, although the Code permits courts to lift the automatic stay in certain instances, ${ }^{\text {" }}$ such situations are specifically enumerated in the language of the Code, and are therefore distinct from situations involving prepetition payments. Under a textualist interpretation of the Bankruptcy Code, the express provisions that permit lifting the automatic stay, combined with the lack of statutory language allowing for prepetition payments, require an interpretation of the Code in which the

als Inc, Case No 98-02179 (Bankr D Del, filed Sept 28, 1998); In re WSR Corp, Case No 98-01241 (Bankr D Del, filed June 9, 1998); In re FF Holdings Corp and Farm Fresh, Inc, Case Nos 9800037 and 98-00038 (D Del, filed Jan 7,1998).

68 See Patricia L. Barsalou, Preferential First-Day Orders - A Question for Congress, 13 Jun Am Bankr Inst J 19 (describing the courts of appeal refusing payments to prepetition creditors compared with the preference of lower courts to avoid strict adherence to the Bankruptcy Code, and determining that perhaps the lower courts are asking Congress to fix the problem).

69 Amendments to the Bankruptcy Code are currently pending in Congress, but do not include provisions for prepetition payments. See HR 333, 107th Cong, 1st Sess, in 147 Cong Rec H 517 (Mar 1, 2001); Conference Report on HR 333, HR Rep No 107-617, 107th Cong, 2d Sess, in 148 Cong Rec H 5704 (July 25, 2002). If the bankruptcy system suffers from the elimination of prepetition payments, Congress is free to amend the Code to include them. Nonetheless, Congress, not the courts, should ultimately determine whether prepetition payments should be a viable aspect of the bankruptcy process.

70 See note 58 .

71 See, for example, 11 USC $\$ 362$ (d)(1) (providing for relief from the automatic stay when a party lacks adequate protection of a property interest). 
automatic stay must be left in place until judicial confirmation of a plan occurs. $^{72}$

In addition to the specific text of the Code, the legislative history ${ }^{73}$ shows that Congress knew about the necessity of payment rule, yet definitively excluded it from the Code. ${ }^{74}$ According to the Senate Report accompanying the 1978 Act, Congress specifically enacted Section 1171(b) of the Code to permit necessary creditors of railroads to recover claims pursuant to the "priority traditionally accorded" such creditors. ${ }^{75}$ Yet, despite understanding the rule and its implications for prepetition payments, Congress did not implement the rule anywhere else in the Code. ${ }^{76}$

Given the Code's statutory language and legislative history, the federal appellate courts' interpretation is accurate. Further, the uniformity of the appellate court decisions in non-railroad cases puts forth the correct interpretation of the Code's language and meaning. Because the proper role of the courts is to enforce and adhere to the plain meaning of the Code's language, the appellate courts are correct in refusing to permit prepetition payments."

72 This Comment's conclusion as to the appellate courts' accurate interpretation of the Code applies a textualist reading to the Code's language. Textualism requires that an interpreter rely only on the meaning that "an ordinary speaker of the English language would draw from the statutory text." William N. Eskridge, Jr., Philip P. Frickey, and Elizabeth Garrett, Legislation and Statutory Interpretation 228 (2000). An interpretation of the Bankruptcy Code's language using this approach leads to the conclusion that prepetition payments are not included, and therefore are prohibited.

73 Although a textualist reading of the Code would not consider legislative history as relevant to the correct interpretation of the statutory language, see id at 228-29, the solution considers and discusses the Code's history as further evidence of the assertion that prepetition payments are not permitted under the Bankruptcy Code.

74 See S Rep No 989, 95th Cong, 2d Sess 136 (1978), reprinted in 1978 USCCAN 5922 (explaining that the act would continue to allow courts in railroad reorganizations to approve payments from a debtor's estate if the public interest in continued rail service outweighed adverse effects on creditors). The inclusion of the necessity of payment rule for railroad reorganizations shows Congress's awareness of the doctrine, and its failure to expand the rule to other areas of the Code evidences Congress's choice not to do so.

75 Id.

76 Because Congress intended the automatic stay as "a fundamental protection for debtors," by circumventing the automatic stay requirement, prepetition payments appear to contravene the congressionally designed bankruptcy system. See id at 5840-41.

77 Although frequently debated, the role of courts from a textualist standpoint is to interpret the law as written. In this context, the appellate courts' reading of the Code is accurate due to the lack of a specific provision in the Code permitting prepetition payments. See Antonin Scalia, A Matter of Interpretation 23 (Princeton 1997) (asserting that the role of judges is to follow the plain meaning of statutes when interpreting their language). 


\section{B. Tipping the Balance: Why Prepetition Payments are Not Required to Fulfill the Code's Purposes}

In addition to a lack of textual authorization for prepetition payments, the Code's purposes do not require the use of prepetition payments. ${ }^{78}$ Nothing in the Code provides that a debtor must reorganize; ${ }^{79}$ rather, Bankruptcy provides only an opportunity to reorganize. In this light, eliminating prepetition payments does not alter the underlying purpose of the Code because it only affects the specific means by which reorganization is to take place.

Eliminating prepetition payments will inevitably hurt the ability of some firms to reorganize. ${ }^{81}$ Not all firms, however, require prepetition payments to reorganize, and moreover, the bankruptcy process itself was not created to guarantee a successful reorganization, only a fair process. ${ }^{82}$ Under the solution, the Code and its provisions will remain intact, providing protection for future distressed firms seeking opportunities for reorganization. Although prepetition payments can assist in a firm's reorganization, their presence during the process is not necessarily tied to the system's overall ability to provide opportunities to reorganize. ${ }^{83}$ Instead, the use of prepetition payments has altered the landscape of the bankruptcy system set forth in the Code.

When a prepetition payment is granted, the court is inherently taking sides at the beginning of a case. ${ }^{84}$ Despite the Code's attempt to provide a neutral ground for the reorganization process, the court that grants prepetition payments is automatically siding with those credi-

78 The Code's requirement that all creditors participate in the process means that certain firms will inevitably face opposition in their attempt to reorganize. A firm failing to reorganize due to an inability to make prepetition payments is no different from a firm that fails to reorganize from an inability to successfully implement a plan over the objection of powerful creditors. See 11 USC $\$ 1129$ (requiring participation of all creditors before confirmation is permitted).

79 The Code only provides that firms can file for Chapter 11 protection. It does not promise a successful reorganization. On the contrary, numerous provisions exist whereby a debtor must gain certain approvals before any reorganization plan can be successfully confirmed or implemented. See 11 USC $\$ 1129$. See also note 15 .

80 The solution does not remove the protections of bankruptcy from a firm's grasp. Instead it alters the rules of the process to conform to those set forth in the Code.

81 The solution's reality is that firms will be powerless to pay essential suppliers prior to confirmation, and will therefore have no ability to guarantee full payment of prior debts in exchange for continued shipments of goods and services. As a result, firms in Chapter 11 would be more likely to lose certain suppliers as continuing business partners.

82 Although the solution destroys the ability of some firms to use bankruptcy successfully, other firms will still be able to reorganize. See Part III.C.

83 Not all past reorganizations have required prepetition payments. See, for example, In the Matter of Columbia Gas System, Inc, 171 BR 189, 194 (Bankr D Del 1994) (refusing to grant a prepetition payment prior to confirmation).

84 Granting a prepetition payment automatically lessens the initial pro rata distribution value that parties would receive if liquidation occurred instead. Further, not all parties involved want the firm to reorganize-some prefer Chapter 7 liquidation. 
tors that wish to reorganize, and against those creditors who would prefer to liquidate the firm under Chapter $7 .^{85}$ Doing so not only defers to the judgment of certain creditors over others, it ignores the provisions in the Code that provide for equal treatment among all creditors. ${ }^{86}$ Because nothing in the Code requires a successful reorganization, a court's intervention in granting prepetition payments can be a premature decision with a detrimental impact on numerous creditors. $^{87}$ By tipping the balance in favor of reorganization, courts move beyond the Code's intended purpose of providing reorganization opportunities, and instead jump to the conclusion that the firm can and should reorganize.

\section{Assessing the Impact: A Detrimental but Necessary Effect on Bankruptcy Efficiency}

Although required by the language of the Bankruptcy Code, eliminating prepetition payments would have a detrimental effect on the overall efficiency of the bankruptcy regime. In the current bankruptcy system, two types of cases exist: a) prepackaged deals, and b) heavily contested workouts. When observed in light of these cases, the solution will impact both types of cases within the overall bankruptcy system.

\section{Prepackaged bankruptcy reorganization plans.}

The majority of corporate bankruptcy cases are handled in prepackaged deals in which the various creditors determine the substance of the reorganization process before the bankruptcy petition is even filed. ${ }^{89}$ In these situations, major creditors determine

85 Because the baseline for any reorganization plan is the value of a complete liquidation and pro rata distribution of assets, some creditors would prefer to liquidate and recover a pro rata share than risk losing money in a failed reorganization. Nonetheless, by virtue of filing a Chapter 11 petition, the firm has expressed its desire to reorganize and continue operating as a going concern. These differing views create the tension that fuels litigation over the firm's assets in a reorganization plan. See Part III.C.

86 See 11 USC $\S 1129$ (requiring participation of all creditors before confirmation is permitted).

87 See, for example, In re lonosphere Clubs, Inc, 98 BR 174, 179 (Bankr SD NY 1989) (stating that a prepetition payment to striking and nonworking Eastern Air Lines employees would not increase the probability of a successful reorganization and would harm the interests of other creditors),

88 Because the courts are making such a determination during the first few days of a bankruptcy proceeding, they are necessarily making uninformed conclusions as to the viability of the distressed firm. These assumptions run counter to the Code's balanced approach to various creditors, by providing an unfair advantage to parties that favor reorganization.

89 See, for example, Sandra E. Mayerson, Current Developments in Prepackaged Bankruptcy Plans, 838 PLI/Comm 337, 339-40 (2002) (explaining that prepackaged bankruptcy plans have been used since the $1930 \mathrm{~s}$, and recently have become a widely used tool to streamline the 
how much each class of creditors will receive, ${ }^{90}$ which prepetition creditors will be paid in full, and the extent to which administrative costs will be paid." Although certain contingencies can arise that require alterations to the prepackaged plan, in general, these reorganizations occur as originally planned. Nonetheless, prepetition payments are sometimes made in the event a contingency arises that would delay the plan's confirmation."

Eliminating prepetition payments would limit, but not destroy, the ability to use prepackaged plans in bankruptcy practice. Plans that are confirmed shortly after the prepetition payments are made would delay these payments until the plan was confirmed and implemented." Admittedly, this solution increases the amount of power creditors opposed to the reorganization would hold in the prepackaged negotiations. ${ }^{\text {sh }}$ Eliminating prepetition payments as a potential tool in prepackaged plans, however, does not necessarily foreclose the use of such plans. Instead, the solution forces the timing of the payments contemplated by each plan to comply with the Code's statutory requirements. $^{96}$

bankruptcy process by reducing time and expense through negotiations before a debtor has filed its petition); Susan Carey, American Airlines' TWA Financing Plan is Approved, Although Rivals Cry Foul, Wall St J A3 (Jan 29, 2001) (describing TWA's prepackaged reorganization plan to sell its assets to American Airlines).

90 In a Chapter 11 reorganization plan, creditors are divided into classes based on the amount and type of claim owed. Prepackaged plans allow parties to create these various classes of claims before the bankruptcy petition is filed, thereby diminishing the amount of work required during the postpetition bankruptcy hearings.

91 See generally Mayerson, $838 \mathrm{PLI} / \mathrm{Comm}$ at $340-42$ (cited in note 89) (describing the means by which prepackaged plans are implemented under the Bankruptcy Code and Rules); 11 USC \$ 1102(b) (allowing a prepetition negotiation committee to act as a final creditors' committee in bankruptcy); 11 USC $\S 1121$ (a) (allowing the debtor to file its plan of reorganization simultaneously with the petition for bankruptcy); 11 USC $\$ 1126$ (b) (allowing claim holders to be deemed to have rejected or accepted a plan before the bankruptcy case is commenced).

92 Generally, however, prepetition payments are unnecessary in prepackaged reorganization plans since the reorganization plan is usually confirmed shortly after the bankruptcy petition is filed. See Mayerson, $838 \mathrm{PLI} / \mathrm{Comm}$ at $341-42$ (cited in note 89) (describing the usual means by which prepackaged plans are implemented).

93 The gap between payment to prepetition creditors and confirmation of a prepackaged plan is generally short enough that the firm's operations would not suffer from the wait.

94 The solution would effect the ability of some firms to use prepackaged plans, particularly where strong creditors hold out and oppose reorganization. Yet, as Mayerson points out, the expediency associated with prepackaged bankruptcies makes them an attractive means to reorganize. See $838 \mathrm{PLI} / \mathrm{Comm}$ at 342 (cited in note 89).

95 The solution could create a holdout problem, as small creditors find themselves with more clout in the overall reorganization process. Major creditors, however, could use measures to minimize the holdout power of parties through strategic classification of claims, cramdown, or by bowing to demands of the holdouts. See 11 USC $\S 1129$ (describing the means by which a contested reorganization plan can be confirmed). See also note 108 .

96 Sections 1122 and 1129 clearly set forth the requirement for classification of claims in a reorganization plan, and this solution does not alter the terms of that section in any way. 11 USC $\S \S 1122,1129$. 
Although prepackaged plans with unknown contingencies are more problematic, the solution does not prevent successful implementation of these plans either. First, filing the bankruptcy petition could be delayed until the plan is organized more effectively: The solution requires more careful and effective structuring of prepackaged reorganizations to ensure that all problems are ironed out before implementation. ${ }^{\text {gn }}$ If the parties take longer to organize the prepackaged deal, they are more likely to avoid objections that would hold up confirmation once the bankruptcy petition is filed and the plan is announced. ${ }^{98}$ Second, because the plan is "prepackaged," the bulk of negotiations would have already been finished. Because the nature of a prepackaged reorganization inherently allows for faster resolution of issues, the solution should not inhibit the ability to successfully structure and implement prepackaged reorganization plans."

\section{Heavily contested reorganizations.}

The solution is more likely to affect heavily contested cases. ${ }^{100}$ In contested bankruptcies, creditors either disagree with parts of proposed plans, or prefer liquidation and payment. ${ }^{101}$ In these cases, eliminating prepetition payments could in effect sound the death knell for the debtor before a reorganization plan is ever proposed or confirmed.

Thus, the solution would prevent certain firms from successfully reorganizing. Yet, because these bankruptcies are contested, certain parties may not want the firm to reorganize in the first place, thereby

97 The necessary negotiations in a prepackaged bankruptcy are only altered in that the leverage of parties who prefer liquidation is increased. This leverage, however, does not doom a prepackaged deal; instead it forces those bargaining to offer these creditors amounts beyond what would be received in a Chapter 7 liquidation. See 11 USC $\$ 1126$ (f) (stating that classes unimpaired by a plan are deemed to have accepted it, where impaired is defined as one who would receive less than they would under a Chapter 7 liquidation).

98 Effective negotiating and bargaining could combat any potential holdout problem. Further, nothing in the Code prevents creditors or interested third parties from making payments themselves to necessary suppliers, so long as the payments do not come from the debtor's estate. Under the solution, prepackaged deals could continue if essential suppliers were paid by the creditors pushing for a successful reorganization.

99 The amount of time necessary to finish negotiating the reorganization might not be so lengthy as to cause problems and inhibit the production of an effective plan. See Mayerson, 838 PLI/Comm at 344 (cited in note 89) (stating that most practitioners believe that the risk inherent in a prepackaged plan is more than compensated for by the overwhelming savings of time and expense of a prepackaged plan).

100 These cases include situations where many creditors would prefer liquidating the firm under Chapter 7 instead of reorganizing under Chapter 11. See Baird, Elements of Bankruptcy at 16-17 (cited in note 12) (describing the purposes and processes of a Chapter 7 liquidation).

101 In these cases, prepetition payments are used as a means to keep the debtor running while its reorganization plan is arranged and eventually confirmed. See, for example, Just for Feet, 242 BR at 826. 
creating a contrast in views as to whether a reorganization plan should be implemented at all. ${ }^{102}$

On the one hand, the debtor is not ruined by the inability to pay its "essential" suppliers; it is only limited in when it can pay them. ${ }^{103}$ On the other hand, a failure to obtain essential supplies while a long bankruptcy process continues could destroy a firm's ability to operate. $^{104}$

Regardless, there are reasons why this may not matter: For example, bankruptcy is not meant to save all firms. ${ }^{105}$ If a sufficient number of creditors oppose reorganization, or if the firm is doomed to fail despite the ability to reorganize, prepetition payments can end up wasting assets of the firm, as liquidation would be inevitable. ${ }^{106}$ Furthermore, the presence of opposing creditors indicates that this is more likely to be the case than in prepackaged deals.

Even if a firm should be able to reorganize, the existence of opposing creditors would help shape the reorganization process. Eliminating prepetition payments would not end the ability to reorganize, but would force the process through the jaws of opposing creditors who previously held less clout in the overall system. ${ }^{107}$ Hence, the solution's true impact is to alter the balance of power between creditors. ${ }^{106}$

102 The inability to reorganize is not necessarily a bad result. As Professors Baird and Rasmussen argue, Chapter 11 reorganizations have recently begun to benefit only a shrinking minority of parties and creditors. See Douglas G. Baird and Robert Rasmussen, The End of Bankruptcy, 55 Stan L Rev 751, 788-89 (2002) (pointing out that the primary beneficiaries of Chapter 11 reorganizations are the owner-managers of small bankrupt firms who are seeking to maintain control of the company).

103 If a plan is organized effectively, it can still proceed by paying essential creditors as part of the overall reorganization plan. For example, Swingline would still receive payments for its previous shipments of staplers to Milton's. Further, as an incentive to the essential creditors and suppliers, the reorganization plan could be constructed to pay those creditors more than other non-essential creditors, thereby helping to ensure that its essential suppliers would continue to do business.

104 If essential suppliers did refuse to deal with a firm, the firm might not survive in the interim period. A long interim period can drain a firm of its assets, as it continues to operate under what was a failing business structure, and awaits what it hopes will be a successful financial restructuring.

105 As Professor Douglas Baird has often stated, bankruptcy cannot make a bad restaurant's food taste good. See Baird, Jackson, and Adler, Bankruptcy at 25-26 (cited in note 11) (discussing the difference between financial and economic distressed firms, and the tendency of economically distressed firms to fail despite reorganization).

106 Furthermore, permitting reorganization does not necessarily guarantee a firm's success. The highly publicized Eastern Air Lines case exemplifies a scenario where reorganization allowed the firm to continue, but in reality put off the inevitable liquidation and cost the creditors money in the interim. See In re Ionoshpere Clubs, 98 BR at 176, 179 (acknowledging that prepetition payments were allowed to some Eastern Air Lines employees). See also Tomkins, Eastern Air Poised to Emerge from Bankruptcy, Fin Times at 28 (cited in note 46) (describing the Eastern reorganization plan); Francis Grab, Share the Pain, Share the Gain, 24 Transp L J 1, 20 (arguing that the eventual failure of the reorganization efforts was probably inevitable); note 109 .

107 See note 95. See also Part III.B.

108 Altering the balance of power might not be detrimental, as the Bankruptcy Code pro- 
Further, because bankruptcy is not a zero-sum game, allowing prepetition payments takes money directly from the parties that might oppose those payments in the first place. ${ }^{109}$ Despite altering the current regime, eliminating prepetition payments is necessary to allow a correct implementation of the Bankruptcy Code, and to maintain order within both the bankruptcy system and the federal judiciary.

\section{CONCLUSION}

It is important to quiet bankruptcy's "rebellion" in order to preserve the basic underpinnings of our legal system. Although the overall expediency of the bankruptcy regime might suffer, ${ }^{110}$ eliminating prepetition payments is necessary to preserve both the proper application of the Bankruptcy Code, and the proper hierarchy within the federal judiciary. Permitting the lower court prepetition "rebellion" to continue sets a bad example for the rest of the country's legal regimes. A strong and stable judiciary depends on the willingness of courts to follow precedent dictated by those situated higher in the judicial system. By enforcing and implementing a correct application of the law, the federal appellate courts can protect the integrity of their decisions, restore the force of the Code, and finally quash bankruptcy's "rebellion."

vides a means by which plans can be confirmed despite opposition of parties with claims. Under "cramdown," a reorganization plan can achieve confirmation so long as one detrimentally affected class of creditors approves and one disapproves. See 11 USC § 1129(b) (describing the means by which a reorganization plan can be implemented under the Code). See also Part I.A.2.

109 Assuming that some creditors oppose the prepetition payment, removing money from the finite pool of assets hurts those creditors, and undermines the bankruptcy regime's solution to the collective action problem. Further, although certain payments such as administrative costs are permitted during the reorganization process, Congress has specifically determined in the language of the Code itself that the use of such assets is acceptable. See 11 USC $\$ \$ 503,507$ (permitting use of the estate's assets to pay administrative costs).

110 Harming the bankruptcy system's expediency might not be a detrimental result. Professors Baird and Rasmussen have recently argued that corporate reorganizations "have all but disappeared," and that firms are mostly using Chapter 11 to "sell their assets and divide up the proceeds." If, as they argue, the days of corporate reorganizations have truly ended, adverse effects on the system's expediency would be irrelevant. Baird and Rasmussen, The End of Bankruptcy, 55 Stan L Rev at 751 (cited in note 102). 